\title{
First study of susceptibility and resistance status to pyrethroids insecticides in Anopheles (Cellia) sergentii (Theobald, 1907) from Southern Tunisia
}

\author{
Ahmed Tabbabi, Jabeur Daaboub
}

\author{
Department of Hygiene and Environmental Protection, Ministry of Public Health, Tunis, Tunisia
}

\begin{abstract}
Background: Insecticide resistance is an important threat to malaria control. Anopheles (An.) sergentii proved to be the number one vector in the oases and may be of a particular interest in projection of the future trends of the disease in Tunisia.

Objectives: Resistance status to pyrethroids insecticides in An. sergentii was evaluated for the first time in Tunisia.

Methods: Diagnostic resistance tests to pyrethroids insecticides were conducted on late third and early fourth larvae of $A n$. sergentii collected in Southern Tunisia.

Results: The level of resistance to permethrin and deltamethrin varied from 1.9 to 5.77 and from 2.75 to 4.63 , respectively. The highest resistance was recorded in sample \# 3 to the two used insecticides. Synergists showed that esterases and glutathione-S-transferase were not involved in the resistance to any of the evaluated insecticides. In contrast, cytochrome-P450 monooxygenases played a role in the detoxification of two among three studied samples. Positive correlations between larval tolerance to both Permethrin/DDT and Deltamethrin/DDT were recorded indicated target site insensitivity.

Conclusion: Continued monitoring of insecticide susceptibility and generating complementary data on mechanisms of resistance using molecular and biochemical methods is essential to ensure early detection of insecticide resistance in potential malaria vectors in Tunisia.
\end{abstract}

Keywords: Anopheles sergentii, Pyrethroids insecticides, Tunisia.

DOI: https://dx.doi.org/10.4314/ahs.v18i1.8

Cite as: Tabbabi A, Daaboub J. First study of susceptibility and resistance status to pyrethroids insecticides in Anopheles (Cellia) sergentii (Theobald, 1907) from Southern Tunisia. Afri Health Sci 2018;18(1): 48-54. https:// dx.doi.org/10.4314/abs.v18i1.8

\section{Introduction}

In Tunisia, malaria was the most important vector-born-disease until its elimination in $1980^{1}$. It is caused by parasites of the genus Plasmodium (P.) which are transmitted to humans via the bites of females mosquitoes of the genus Anopheles. Historically, only three species of anophelines are known to be the malaria vectors: Anopheles (An.) labranchiae in Northern Tunisia, and An. sergentii

\section{Corresponding author: \\ Ahmed Tabbabi, \\ Department of Hygiene \\ Environmental Protection, \\ Ministry of Public Health, \\ Tunis, Tunisia. \\ Email: tabbabiahmed@gmail.com}

and An. multicolor in Southern Tunisia (Wernsdorfer W and Iyengar MO, unpublished data). An. sergentii proved to be the number one vector in the oases and may be of a particular interest in projection of the future trends of the disease in Tunisia. Due to the climate change, Tunisia was at risk of lack of water and reduction in crop productivity that's why the underground water reserves in Southern Tunisia were used in irrigation/agricultural projects. Under these conditions, the malaria vector of oases (An. sergentii) may easily emerge and settle down. These observations could be associated with the increase of the annual incidence of imported cases of malaria and highlight the risk of a resumption of the disease transmission in Tunisia ${ }^{2-5}$.

It should be noted that since 1903 and mainly after the World War II, intensive chemical control of malaria vectors have led to successful interruption of autochthonous

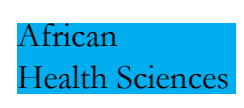

@ 2018 Tabbabi et al; licensee African Health Sciences. This is an Open Access article distributed under the termsof the Creative commons Attribution License (https://creativecommons.org/licenses/by/4.0), which permits unrestricted use, distribution, and reproduction in any medium, provided the original work is properly cited. 
malaria transmission ${ }^{3,6}$. However, this has been limited by the development and spread of resistance ${ }^{7}$. The problem of insecticide resistance is very real and growing in Tuni$\operatorname{sia}^{7-9}$. Effects of climate change and the concern that the mosquitoes are becoming resistant to the entire classes of insecticide in use including pyrethroids may aggravate the situation. It is important to note that resistance of Anopheles mosquitoes to pyrethroid insecticide have never been studied in Tunisia. Their susceptibility to organophosphates insecticides was only approximated by some bioassays on small sample without estimation of involved mechanisms ${ }^{10}$. Generally, two major mechanisms are involved in pyrethroids insecticides resistance: (1) the knockdown resistance phenotype, $(\mathrm{kdr})$ occurs due to a point mutation in the voltage gated sodium channel in the central nervous system, the common target of pyrethroids and DDT; and (2) the increased metabolic detoxification of insecticides including three major enzyme superfamilies: Esterases, Multi function Oxidases P450 and Glutathion-S Transferases ${ }^{11,12}$.
The bionomics of $A n$. Sergentii, its ability to transmit strains of tropical $P$. falciparum and its susceptibility status to insecticides are unknown and poorly documented. It is the specific characteristics that need to be studied in order to improve epidemiological surveillance. The present study aimed to evaluate the susceptibility and resistance status to pyrethroids insecticides in An. sergentii (Theobald, 1907) for the first time in Tunisia.

\section{Material and methods}

\section{Study area and mosquito collection sites}

The study was carried out on $A n$. sergentii mosquitoes from three breeding sites in SouthEast and SouthWest Tunisia (Figure 1) between September and November 2016. Mosquitoes were collected from a ditch, river and water pond. The studied areas are not submitted to agricultural pest control but frequently to mosquito control using organophosphates and pyrethroids insecticides (Table 1).

Table 1: Geographic origin of Tunisian populations of An. (Cellia) sergentii Theobald, 1907, breeding site characteristics, and insecticide control

\begin{tabular}{cllclc}
\hline Code & Governorate & $\begin{array}{c}\text { Breeding } \\
\text { sites }\end{array}$ & $\begin{array}{c}\text { Date of } \\
\text { collection }\end{array}$ & $\begin{array}{c}\text { Mosquito control (used } \\
\text { insecticides) }\end{array}$ & $\begin{array}{c}\text { Agricultural } \\
\text { pest control }\end{array}$ \\
\hline 1 & Tozeur & Ditch & Sep. 2016 & Frequent (C, Pm, F, P, D) & None \\
2 & Tataouine a & River & Nov. 2016 & Frequent (C, Pm, P, D) & None \\
3 & Tataouine b & Water pond & Nov. 2016 & Frequent (C, Pm, P, D) & None \\
\hline
\end{tabular}

C : Chlorpyrifos; Pm : Pirimiphos methyl; F : Fenitrithion; P : Permethrin; D : Deltamethrin 


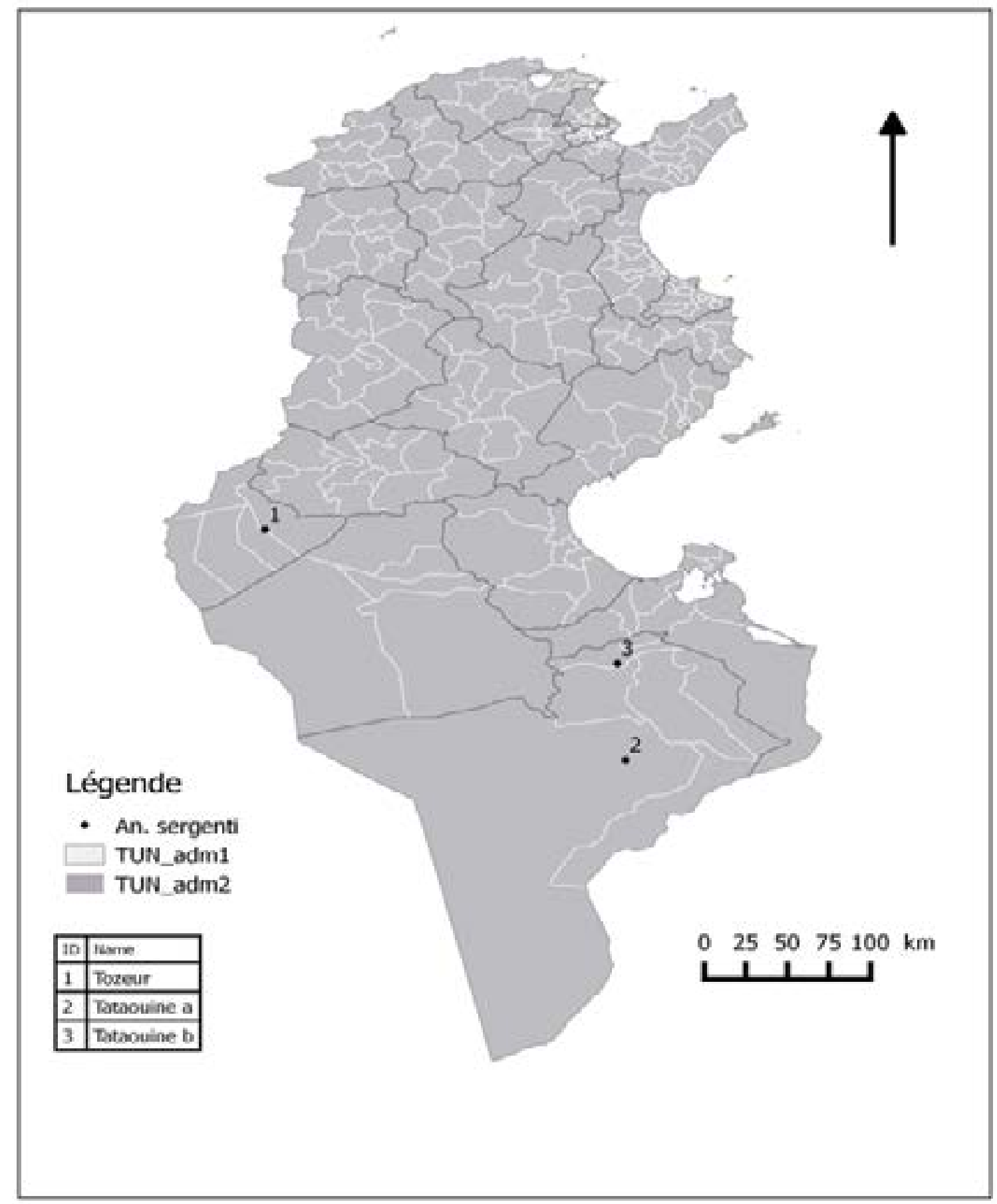

Figure 1: Geographic origin of Tunisian populations

\section{Mosquito strains}

Late third and early fourth larvae of $A n$. sergentii were collected and used for insecticide and synergist bioassays. The morphological identification was carried out using identification software of mosquitoes of the Mediterranean Africa ${ }^{13}$. A sensitive strain collected from Southern Tunisia and showed high susceptibility to pyrethroid in- secticides was used for comparison with resistant collected populations.

\section{Insecticides and synergists}

Three technical-grade insecticides were used for bioassays: the pyrethroid permethrin (94.6Vo, ICI Americas, Inc., Richmond, CA), the pyrethroid deltamethrin 
(95.7Vo, ICI Americas, Inc., Richmond, CA), and the organochloric DDT (99.9Vo; Mobay). Two synergists were used to help detect detoxification enzymes involved in resistance: S,S,Sributyl phosphorothioate (DEF), an esterase inhibitor, and piperonyl butoxide (PB), an inhibitor of mixed function oxidases.

\section{Diagnostic resistance and synergy tests}

Diagnostic tests were conducted on late third and early fourth larvae of $A n$. sergentii using the standard methods of Raymond et $\mathrm{al}^{14}$. Three replicates of 20 mosquitoes were tested against each concentration. Twenty mosquito larvae were placed in $100 \mathrm{ml}$ cup containing $99 \mathrm{ml}$ of distilled water. A series of test concentrations, dissolved in ethanol, were added to give the aimed final concentrations. Five replicates without insecticides were used for control. A series of concentration was used to obtain mortality response from 0 to $100 \%$. To verify that the concentrations of synergist were below toxic levels, standard sub lethal doses of $0.08 \mathrm{mg} / 1$ for DEF, and 2.5 $\mathrm{mg} / \mathrm{l}$ for $\mathrm{Pb}, 4$ hours before the addition of the insecticide were used.

\section{Data analysis}

Mortality data were analyzed using log dose-probit mortality software developed by Raymond et $\mathrm{al}^{15}$ based on Finney ${ }^{16}$. This program is able to do the probit regression analysis, the comparison of probit lines by testing parallelism of slopes, and to produce confidence limits of resistance ratios. When mortality data were not linear but rather displayed a plateau, values for lethal concentrations were approximated graphically after plotting on log-probit paper. Frequencies of resistant individuals were compared using chi-squared contingency tables.

\section{Results}

As shown in Table 2, the results on bioassays tests showed that $A n$. sergentii was resistant to permethrin and deltamethrin but not exceeded 5 -folds. The level of resistance varied from 1.9 to 5.77 and from 2.75 to 4.63 , respectively. The highest resistance was recorded in sample \# 3 to the two used insecticides. Slope values reported the linearity of all studied samples ( $p>0.05)$ indicating a homogeneity of considered phenotype in different studied strains (Table 2).

\section{Table 2a: Permethrin resistance characteristics of Tunisian $\mathbf{A n}$. (Cellia) sergentii Theobald, 1907 in presence and absence of synergists DEF and $\mathrm{Pb}$}

\begin{tabular}{|c|c|c|c|c|c|c|c|c|c|c|c|c|c|}
\hline \multirow[t]{2}{*}{ Population } & \multicolumn{3}{|c|}{ Permethrin } & \multicolumn{5}{|c|}{ Permethrin +DEF } & \multicolumn{5}{|c|}{ Permethrin $+\mathrm{Pb}$} \\
\hline & $\begin{array}{c}\mathrm{LC}_{50} \text { in } \\
\mu \mathrm{g} / \mathrm{l} \\
\text { (a) }\end{array}$ & $\begin{array}{l}\text { Slope } \\
\pm \text { SE }\end{array}$ & $\begin{array}{l}\mathrm{RR}_{50} \\
\text { (a) }\end{array}$ & $\begin{array}{l}\mathrm{LC}_{50} \text { in } \mu \mathrm{g} / \mathrm{l} \\
\text { (a) }\end{array}$ & $\begin{array}{l}\text { Slope } \\
\pm \text { SE }\end{array}$ & $\begin{array}{c}\mathrm{RR}_{50} \\
\text { (a) }\end{array}$ & $\begin{array}{l}\mathrm{SR}_{50} \\
\text { (a) }\end{array}$ & RSR & $\begin{array}{c}\mathrm{LC}_{50} \text { in } \\
\mu \mathrm{g} / \mathrm{l} \\
\text { (a) }\end{array}$ & $\begin{array}{l}\text { Slope } \\
\pm \text { SE }\end{array}$ & $\begin{array}{c}R_{50} \\
\text { (a) }\end{array}$ & $\begin{array}{c}\mathrm{SR}_{50} \\
\text { (a) }\end{array}$ & RSR \\
\hline Sensitive strain & $\begin{array}{c}2.2 \\
(1.5-4.6)\end{array}$ & $\begin{aligned} & 2.12 \\
\pm & 0.74\end{aligned}$ & - & $\begin{array}{c}1.8 \\
(1.1-2.5)\end{array}$ & $\begin{array}{c}2.3 \\
\pm 0.45\end{array}$ & - & $\begin{array}{c}1.22 \\
(0.9-2.7)\end{array}$ & - & $\begin{array}{c}1.4 \\
(0.89- \\
2.4)\end{array}$ & $\begin{array}{c}2.12 \\
\pm 0.87\end{array}$ & - & $\begin{array}{c}1.57 \\
(0.94- \\
3.2)\end{array}$ & - \\
\hline 1-Tozeur & $\begin{array}{c}4.2 \\
(3.4-5.9)\end{array}$ & $\begin{array}{c}1.47 \\
\pm 0.13\end{array}$ & $\begin{array}{c}1.9 \\
(1.1-3.1)\end{array}$ & $\begin{array}{c}5.3 \\
(3.9-6.3)\end{array}$ & $\begin{array}{l}1.13 \\
\pm 0.85\end{array}$ & $\begin{array}{c}2.94 \\
(1.6- \\
3.8)\end{array}$ & $\begin{array}{c}0.79 \\
(0.14-1.22)\end{array}$ & 0.64 & $\begin{array}{c}5.4 \\
(4.9-6.4)\end{array}$ & $\begin{array}{l}1.65^{*} \\
\pm 0.3\end{array}$ & $\begin{array}{l}3.87 \\
(2.2- \\
5.6)\end{array}$ & $\begin{array}{c}0.77 \\
(0.24- \\
0.97)\end{array}$ & 0.49 \\
\hline 2-Tataouine a & $\begin{array}{c}6.4 \\
(5.2-7.8)\end{array}$ & $\begin{array}{r}3.12 \\
\pm 0.77\end{array}$ & $\begin{array}{c}2.9 \\
(1.78- \\
4.25)\end{array}$ & $\begin{array}{c}4.8 \\
(3.2-6.4)\end{array}$ & $\begin{array}{l}1.92 \\
\pm 0.21\end{array}$ & $\begin{array}{l}2.66 \\
(1.4- \\
3.89)\end{array}$ & $\begin{array}{c}1.33 \\
(0.54-1.99)\end{array}$ & 1.09 & $\begin{array}{l}4.98 \\
(3.3- \\
6.45)\end{array}$ & $\begin{array}{c}2.97 \\
\pm 0.27\end{array}$ & $\begin{array}{c}3.55 \\
(2.45- \\
6.5)\end{array}$ & $\begin{array}{l}1.28 \\
(1.1- \\
1.78)\end{array}$ & 0.81 \\
\hline 3-Tataouine b & $\begin{array}{c}12.7 \\
(10.9-15.3)\end{array}$ & 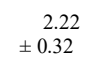 & $\begin{array}{r}5.77 \\
(3.45- \\
7.29)\end{array}$ & $\begin{array}{c}10.89 \\
(8.52-12.78)\end{array}$ & $\begin{array}{c}1.45 \\
\pm 0.28\end{array}$ & $\begin{array}{l}6.05 \\
(3.7- \\
8.21)\end{array}$ & $\begin{array}{c}1.16 \\
(0.8-2.6)\end{array}$ & 0.95 & $\begin{array}{l}10.8 \\
(8.8- \\
12.4)\end{array}$ & $\begin{array}{r}1.26 \\
\pm 0.34\end{array}$ & $\begin{array}{l}7.71 \\
(4.7- \\
8.9)\end{array}$ & $\begin{array}{l}1.17 \\
(0.8- \\
2.5)\end{array}$ & 0.74 \\
\hline
\end{tabular}


In the presence of $\mathrm{Pb}(2.5 \mathrm{mg} / \mathrm{l}$ applied four hours before the treatment), the toxicity of deltamethrin significantly increased in samples \# 1 and 3 (Table 2). The median-lethal doses of deltamethrin (7.5 and 8.8 respectively) were about 7 and 10 times lower than that obtained without synergists. This indicates that cytochrome-P450 monooxygenases played a role in the detoxification of these two samples.

Applying DEF at $0.08 \mathrm{mg} / 1$ four hours prior to treatment with permethrin and deltamethrin had little effect on tox- icity of both compounds (Table 2). The median-lethal dose of the two used compounds was almost unchanged. According to the results obtained from the use of S.S.S. phosphotrithiate trybutil synergist, it was shown that esterases and glutathione-S-transferase were not involved in the resistance to any of the evaluated insecticides.

A positive correlations between larval tolerance to both Permethrin/DDT and Deltamethrin/DDT were recorded (Spearman rank correlation, $(r)=0.83$ and 0.91 , respectively $(\mathrm{P}<0.01))$ indicated target site insensitivity (Voltage-Gated Sodium Channel).

\section{Table 2b: Deltamethrin resistance characteristics of Tunisian An. (Cellia) sergentii Theobald, 1907 in presence and absence of synergists $\mathrm{DEF}$ and $\mathrm{Pb}$}

\begin{tabular}{|c|c|c|c|c|c|c|c|c|c|c|c|c|c|}
\hline \multirow[t]{2}{*}{ Population } & \multicolumn{3}{|c|}{ Deltamethrin } & \multicolumn{5}{|c|}{ Deltamethrin +DEF } & \multicolumn{5}{|c|}{ Deltamethrin +Pb } \\
\hline & $\begin{array}{c}\mathrm{LC}_{50} \text { in } \\
\mu \mathrm{g} / \mathrm{l} \\
(\mathrm{a})\end{array}$ & $\begin{array}{l}\text { Slope } \\
\pm \text { SE }\end{array}$ & $\begin{array}{c}\mathrm{RR}_{50} \\
\text { (a) }\end{array}$ & $\begin{array}{c}\mathrm{LC}_{50} \text { in } \\
\mu \mathrm{g} / \mathrm{l} \\
\text { (a) }\end{array}$ & $\begin{array}{l}\text { Slope } \\
\pm \mathrm{SE}\end{array}$ & $\begin{array}{l}\mathrm{RR}_{50} \\
\text { (a) }\end{array}$ & $\begin{array}{l}\mathrm{SR}_{50} \\
\text { (a) }\end{array}$ & RSR & $\begin{array}{c}\mathrm{LC}_{50} \text { in } \\
\mu \mathrm{g} / \mathrm{l} \\
(\mathrm{a})\end{array}$ & $\begin{array}{l}\text { Slope } \\
\pm \mathrm{SE}\end{array}$ & $\begin{array}{c}\mathbf{R R}_{50} \\
\text { (a) }\end{array}$ & $\begin{array}{l}\mathrm{SR}_{50} \\
\text { (a) }\end{array}$ & RSR \\
\hline $\begin{array}{c}\text { Sensitive } \\
\text { strain }\end{array}$ & $\begin{array}{c}1.9 \\
(1.2-2.8)\end{array}$ & $\begin{array}{r}2.87 \\
\pm 0.76\end{array}$ & - & $\begin{array}{c}1.7 \\
(1.0-2.8)\end{array}$ & $\begin{array}{l}1.99 \\
\pm \\
0.12\end{array}$ & - & $\begin{array}{c}1.11 \\
(0.9-2.1)\end{array}$ & - & $\begin{array}{c}1.3 \\
(0.77-1.86)\end{array}$ & $\begin{array}{c}2.14 \\
\pm \\
0.45\end{array}$ & - & $\begin{array}{c}1.46 \\
(0.85- \\
2.22)\end{array}$ & - \\
\hline 1-Tozeur & $\begin{array}{c}7.5 \\
(5.8-8.9)\end{array}$ & $\begin{array}{r}1.29 \\
\pm 0.45\end{array}$ & $\begin{array}{c}3.94 \\
(2.1-5.7)\end{array}$ & $\begin{array}{c}9.9 \\
(8.4- \\
11.8)\end{array}$ & $\begin{array}{l}1.45 \\
\pm \\
0.35\end{array}$ & $\begin{array}{c}5.82 \\
(4.6-7.42)\end{array}$ & $\begin{array}{c}0.75 \\
(0.35- \\
1.5)\end{array}$ & 0.67 & $\begin{array}{c}1.2 \\
(0.52-1.65)\end{array}$ & $\begin{array}{l}1.23 \\
\pm \\
0.41\end{array}$ & $\begin{array}{c}0.92 \\
(0.47-1.45)\end{array}$ & $\begin{array}{c}6.25 \\
(4.56- \\
7.81)\end{array}$ & 4.28 \\
\hline 2-Tataouine a & $\begin{array}{c}4.9 \\
(2.6-6.7)\end{array}$ & $\begin{array}{r}1.75 \\
\pm 0.22\end{array}$ & $\begin{array}{c}2.57 \\
(1.18-3.45)\end{array}$ & $\begin{array}{c}7.48 \\
(5.78- \\
9.45)\end{array}$ & $\begin{array}{l}0.89 \\
\pm \\
0.15\end{array}$ & $\begin{array}{c}4.4 \\
(3.5-7.9)\end{array}$ & $\begin{array}{c}0.65 \\
(0.22- \\
1.3)\end{array}$ & 0.58 & $\begin{array}{c}3.5 \\
(2.4-4.9)\end{array}$ & $\begin{array}{l}0.81 * \\
\pm \\
0.24\end{array}$ & $\begin{array}{c}2.69 \\
(1.79-3.34)\end{array}$ & $\begin{array}{c}1.4 \\
(0.87- \\
1.97)\end{array}$ & 0.95 \\
\hline 3-Tataouine b & $\begin{array}{c}8.8 \\
(7.2-9.7)\end{array}$ & $\begin{array}{r}1.53 \\
\pm 0.16\end{array}$ & $\begin{array}{c}4.63 \\
(3.2-6.7)\end{array}$ & $\begin{array}{l}10.2 \\
(8.2- \\
12.8)\end{array}$ & $\begin{array}{l}1.41 \\
\pm \\
0.65\end{array}$ & $\begin{array}{c}6 \\
(4.4-8.45)\end{array}$ & $\begin{array}{c}0.86 \\
(0.5-1.7)\end{array}$ & 0.77 & $\begin{array}{c}0.85 \\
(0.24-1.56)\end{array}$ & $\begin{array}{l}1.22 \\
\pm \\
0.53\end{array}$ & $\begin{array}{c}0.65 \\
(0.23-1.42)\end{array}$ & $\begin{array}{l}10.35 \\
(9.33- \\
12.54)\end{array}$ & 7.12 \\
\hline
\end{tabular}

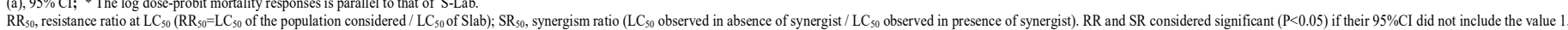
$\mathrm{RSR}$, relative synergism ratio (RR for insecticide alone / RR for insecticide plus synergist).

\section{Discussion}

The results of susceptibility tests using standard methods of Raymond et $\mathrm{al}^{14}$, showed that $A n$. sergentii was lowly resistant to permethrin and deltamethrin insecticides. The difference in resistance levels from one population to another can be explained by their behavioural resistance mechanism. It should be noted that resistance of An. sergentii has never been reported to pyrethroids in Tunisia. Preliminary tests on small sample showed their susceptibilities to organophosphates insecticides in central Tunisia and Morocco ${ }^{10,17}$. Note that various levels of resistance to organophosphate and pyrethroids were also reported in the secondary malaria vector $A$. nuneztovar ${ }^{18}$. The low and moderate resistance in An. sergentii to organophosphates and pyrethroids insecticides presents greater opportunity for managing resistance in Tunisia. Several authors showed the positive correlation between pyrethroids resistance mechanisms and selection pres- sure caused by DDT insecticide used for malaria vector control between 1964 and 1978 in Tunisia ${ }^{7}$ without forgetting the recent frequent mosquito control using organophosphates and pyrethroids insecticides. Therefore, periodic monitoring the resistance status, its mechanisms and study on cross-resistance are necessary to evaluate the insecticides and solve problem of control programs. Noting that other environmental factors like the pollution and the biotic interactions between vectors and other organisms may affect mosquito responses to pyrethrois insecticides.

Several standard methods are frequently used to evaluate resistance to insecticide in malaria vectors. Bioassays are the mains approaches to estimate cross-resistance to commonly used classes of insecticides by identification of resistance mechanisms ${ }^{19}$. In this context, cross-resistance to both Permethrin/DDT and Deltamethrin/DDT 
were tested and showed a positive correlation indicating indicated target site insensitivity as common mechanism (Voltage-Gated Sodium Channel). These results confirm the above findings and the selection pressure with DDT during the national malaria eradication program in the $60 \mathrm{~s}$ and 70s. Many genetic, biological and operational parameters $^{20-22}$ oriented the evolution of insecticides resistance which is very complex. We cited the biological parameters associated with the life cycle of the malaria vector such as the number of generation and the rate of reproduction, migration, and isolation, the genetic parameters including polygenic resistance, dominance, fitness cost and gene interaction. Operational parameters that include the method and frequency of application, dosage and residual activity of the insecticides as well as insecticide coverage.

The metabolic resistance was investigated using synergists which act by blocking metabolic pathways that would otherwise break down insecticides, then restore the susceptibility to the insecticide ${ }^{23-25}$. Synergist's bioassays give us preliminary information on detoxification enzymes co-involved with $\mathrm{kdr}$ mutations in An. sergentii resistance in Tunisia. Our findings showed that esterases and glutathione-S-transferase were not involved in the resistance to any of the evaluated insecticides. In contrast, cytochrome-P450 monooxygenases played a role in the detoxification of two among three studied samples and partial effect for $\mathrm{kdr}$ mutation in shaping resistance to DDT, permethrin and deltamehtrin in field-collected populations ${ }^{26,27}$. Indeed, several studies showed the major contribution of target site in the recorded resistance ${ }^{28}$. On the other hand, Raymond et $\mathrm{al}^{29}$ reported the additive action of detoxification enzymes and target site. DDT, permethrin and deltamethrin resistance was reported in field populations of $A n$. albimanus from Guatemala, whereas full susceptibility was recorded in Anopheles mosquitoes from El Salvador and Belize ${ }^{30,31}$. The strains from Guatemala showed significant increase in activities of esterase and/or oxidase as measured by spectrophotometer showing their involvement in pyrethroid-resistance ${ }^{30}$.

\section{Conclusion}

The low pyrethroids resistance observed in Tunisia malaria vector is particularly interesting, because it leaves a range of tools useable by vector control services. Continued monitoring of insecticide susceptibility and generating complementary data on mechanisms of resistance using molecular and biochemical methods is essential to ensure early detection of insecticide resistance in potential malaria vectors in the region.

\section{Acknowledgments}

We are grateful to the Regional Directories of Public Health. A special thanks to Dr. A Hedfi, Dr. M Raouane, N Shili, T Trilla and A Khlifi for their previous help and effort to identify breeding sites of Anopheles mosquitoes in Southern Tunisia.

\section{Conflict of interest}

The authors declare that they have no conflict of interest.

\section{References}

1. Tabbabi A, Boussès $P$, Rhim A, Brengues C, Daaboub J, Ben-Alaya-Bouafif N, Fontenille D, Bouratbine A, Simard F, Aoun K. Larval habitats characterization and species composition of Anopheles mosquitoes in Tunisia, with particular attention to Anopheles maculipennis complex. American Journal of Tropical Medicine and Hygiene. 2015, 92(3): 653-659.

2. Chadli A, Kennou MF, Kooli J. Le paludisme en Tunisie: historique et e' tat actuel. Bull Soc Pathol Exot 1985, 78: 844-851.

3. Ben Rachid MS, Ben Ammar R, Redissi T, Ben Said M, Hellel H, Bach-Hamba D, el Harabi M, Nacef T. Ge'ographie des parasitoses majeures en Tunisie. Arch Inst Pasteur Tunis 1984, 61: 17-41.

4. Gmara D. Situation actuelle du paludisme dans le monde et en Tunisie (DSSB). 2006, Cairo, Egypt: Reunion OMS.

5. Bouratbine A, Chahed MK, Aoun K, Krida G, Ayari S, Ben Ismail R. Le paludisme d'importation en Tunisie. Bull Soc Pathol Exot 1998, 91: 203-207.

6. Chadli A, Kennoun MF, Kooli J. Les campagnes d'eradication du paludisme en Tunisie: historique et etat actuel. Arch Inst Pasteur Tunis 1986; 63: 35-50.

7. Ben Cheikh H, Haouas-Ben Ali Z, Marquine M, Pasteur N. Resistance to organophosphorus and pyrethroid insecticides in Culex pipiens(Diptera: Culicidae) from Tunisia. J Med Entomol 1998, 35: 251-260.

8. Daaboub J, Ben Cheikh R, Lamari A, Ben Jha I, Feriani M, Boubaker C, Ben Cheikh H. Resistance to pyrethroid insecticides in Culex pipiens pipiens (Diptera: Culicidae) from Tunisia. Acta Trop 2008, 107(1):30-6.

9. Tabbabi A, Daaboub J, Laamari A, Ben Cheikh R, Has- 
sen Ben Cheikh. Pirimiphos-Methyl Resistance Status of Field Populations of Culex pipiens (Diptera: Culicidae) From Grand Tunis Area, Northeast Tunisia. Hereditary Genetics 2017, 6 (1).

10. Krida G, Bouattour A, Rhaim A, El Kebir A, Jlidi R. Investigation préléminaire de la sensibilité au chlorpyrifos de quatre échantillons larvaire d'anopheles de Tunisie. Archive Institute Pasteur Tunis 1998, 75 (3/4): 199-203.

11. Weill M, Marquine M, Berthomieu A, Dubois MP, Bernard C, Qiao CL, Raymond M. Identification and characterization of novel organophosphate detoxifying esterase alleles in the Guangzhou area of China. J Am Mosq Control Assoc 2001, 17: 238-244.

12. Weill M, Lutfalla G, Mogensen K, Chandre F, Berthomieu A, Berticat C, Pasteur N, Philips A, Fort P, Raymond $\mathrm{M}$. Insecticide resistance in mosquito vectors. $\mathrm{Na}$ ture 2003, 423: 136-137.

13. Brunhes J, Rhaim A, Geoffroy B, Angel G, Hervy JP. Les moustiques de l'Afrique mediterraneenne CD-ROM d'identification et d'enseignement, Edition IRD 1999, Montpellier, France.

14. Raymond M, Fournier D, Bride JM, Cuany A, Bergé J, Magnin M, Pasteur N. Identification of resistance mechanisms in Culex pipiens (Diptera: Culicidae) from southern France: insensitive acetylchlinesterase and detoxifying oxidases. J Econ Entomol 1986, 79: 1452-1458.

15. Raymond M, Prato G, Ratsira D. PROBIT. Analysis of mortality assays displaying quantal response. Praxeme (Licence No. L93019) 1993, Saint Georges d’Orques, France.

16. Finney DJ. Probit analysis. Cambridge University Press, Cambridge, 1971.

17. Faraj C, Ouahabi S, Adlaoui E, El Aouad R. Current status of the knowledge on Moroccan Anophelines (Diptera: (Culicidae): Systematic, geographical distribution and vectorial competence [État actuel des connaissancessur les anophèles du Maroc (Diptera: Culicidae): systématique, distribution géographique et compétence vectorielle]. Revue d'Epidémiologie et de Santé Publique 2010, 58 (5): 349-357 18. Fonseca-Gonzalez I, Cardenas R, Quinones ML, McAllister J, Brogdon WG: Pyrethroid and organophosphates resistance in Anopheles (N.) nuneztovari Gabaldon populations from malaria endemic areas in Colombia. Parasitol Res 2009, 105(5):1399-1409.

19. Brodgon WG, McAllister JC, Vulule J. Heme peroxydase activity measured in single mosquitoes identifies individuals expressing an elevated oxidase for insecticide resistance. J Am Mosq Control Assoc 1997, 13:233-237.
20. IRAC: Prevention and Management of Insecticide Resistance in Vectors of Public Health Importance In: Resistance Management for Sustainable Agriculture and Improved Public Health : Second Edition 2010 Insecticide Resistance Action Commitee; 2010:72pp.

21. Georghiou GP, Taylor CE. Genetic and biological influences in the evolution of insecticide resistance. Journal of Economic Entomology 1977, 70(3):319-323.

22. Denholm I, Rowland MW. Tactics for managing pesticide resistance in arthropods: theory and practice. Annu Rev Entomol 1992, 37:91-112.

23. Casida JE. Mixed-function oxydases involvement in the biochemistry. J Agric Food Chem 1970, 18:753-772.

24. Jao LT, Casida JE. Insect pyrethroid-hydrolyzing esterases. Pestic Biochem Physiol 1974, 4:465-472.

25. Pasay C, Arlian L, Morgan M, Gunning R, Rossiter L, Holt D, Walton S, Beckman S, McCarthy J. The effect of insecticide synergists on the response of scabies mites to pyrethroid acaricides. PLoS Negl Trop Dis 2009, 3:e354.

26. Nwane P, Etang J, Chouaibou M, Toto JC, Kerah-Hinzoumbé C, Mimpfoundi R, Awono-Ambene HP, Simard F. Trends in DDT and pyrethroid resistance in anopheles gambiae s.s. Populations from urban and agro-industrial settings in Southern Cameroon. BMC Infect Dis 2009, 9:163.

27. Antonio-Nkondjio C, Tene Fossog B, Ndo C, Menze Djantio B, Zebaze Togouet S, Awono-Ambene P, Costantini C, Wondji C, Ranson H. Anopheles gambiae distribution and insecticide resistance in the citiesof douala and Yaoundé (Cameroon): influence of urban agriculture and pollution. Malaria J 2011, 10:154.

28. Pasteur N, Marquine M, Ben Cheikh H, Bernard C, Bourguet D. A new mechanism conferring unprecedented high resistance to chlorpyrifos in Culex pipiens (Diptera : Culicidae). J Med Entomol 1999, 36: 794-802.

29. Raymond M, Heckel DG, Scott JG. Interactions between pesticide genes. Model and experiment. Genetics 1989, 123: 543-551.

30. Chareonviriyaphap T, Golenda CF, Roberts DR, Andre RG. Identification of Elevated Esterase Activity in a Pyrethroid-Resistant Population of Anopheles albimanus Wiedemann. ScienceAsia. 1999, 25: 153-156.

31. Brogdon WG, McAllister JC, Corwin AM, Cordon Rosales C. Independent selection of multiple mechanisms for pyrethroid resistance in Guatemalan Anopheles albimanus (Diptera: Culicidae). Journal of Economic Entomology. 1999, 92(2):298-302. 